DOI 10.37882/2223-2982.2020.06-2.13

\title{
ЦВЕТОВАЯ ОППОЗИЦИЯ «БЕЛЫЙ-ЧЕРНЫЙ» И ЕЕ РОЛЬ В ЯЗЫКОВОЙ ИНТЕРПРЕТАЦИИ
}

\section{WHITE-BLACK COLOR OPPOSITION AND ITS ROLE IN LINGUISTIC INTERPRETATION \\ Z. Dzagova}

Summary: This article discusses one of the key metaphorical binary oppositions white-black, describes the features of the construction of its semantic space, special attention is paid to the symbolic level-important for understanding complex axiological processes. Based on the data of modern dictionaries, as well as artistic, scientific and journalistic texts of the national corpus of the Russian language, the author distinguishes and characterizes the spheres of life: emotional, ethical, socio-legal and epistemological, for the interpretation of which a person uses this antonymic pair.

Keywords: axiological, symbolic, binary opposition, metaphorical.
$\mathrm{B}$ аксиологическом постижении мира особую роль играет метафорическое использование противоположных понятий, которые создают бинарную оппозицию в языке. Такие антонимические метафоры, свойственные еще мифологическому сознанию, оказывают влияние на мышление и речевое поведение современного человека. Они служат своеобразными маркерами, при помощи которых человек оценивает окружающее пространство. К числу таких аксиологических диад относится и оппозиция «белый/черный», в основе ее лежат два изначально неоценочных цветовых компонента, которые, показывая отражение чувственного восприятия картины мира, «приложимы к более общим ситуациям» [9, с. 11], благодаря чему они создают многослойность содержания и рождают новые, символические смыслы.

Семантическая противопоставленность данных цветовых прилагательных, зафиксированная в современных словарях, по мнению ученых, является результатом исторического развития семантической структуры слова «белый». Реконструкция его семного состава в древнерусском языке, предпринятая В. В. Колесовым, показала, что первоначально основное значение слова не было цветовым: «почти полное отсутствие в древних текстах противопоставления слов «белый-черный» оказывается весьма выразительным доказательством первоначально не цветового значения слова «белый», во всяком случае, неактуальности такого значения в древнерусской системе [5, с. 9].

В русском литературном языке национальной эпохи,

\author{
Дзагова Залина Владимировна \\ Соискатель, Кабардино-Балкарский государственный \\ университет \\ z.dzagova@yandex.ru
}

Аннотация: В данной статье рассматривается одна из ключевых метафорических бинарных оппозиций «белый - черный», описываются особенности построения ее семантического пространства, особое внимание уделяется символическому уровню, важному для понимания сложных аксиологических процессов. С опорой на данные современных толковых словарей, а также художественные, научные и публицистические тексты национального корпуса русского языка выделяются и характеризуются сферы жизнедеятельности, для интерпретации которых человек использует эту антонимическую пару.

Ключевые слова: аксиологический, символический, бинарная оппозиция, метафорический.

как пишет Т.Н. Дорожкина, слова «белый» и «черный» образуют бесспорную антонимическую пару, поскольку их уже отличают все характерные для антонимов признаки: ощутимый носителями языка контраст (что фиксируется памятниками в соответствующем употреблении этих слов, начиная с XIV-XV вв.), большое сходство в функционировании, частая совместная встречаемость в тексте $[4$, c. 8].

В текстах современного русского языка диада «белый-черный» представлена как несомненно аксиологическая. Наряду с такими оппозициями, как свет-тьма, верх-низ, чистый-грязный и т.п., она выступает в русском языковом сознании как мерило действительности. Так, в семантике компонентов диады может подчеркиваться полярность, разведенность по разные концы оценочной шкалы:

Для нее не существует полутонов, только черное и белое (С. Спивакова). Как бы вы ни держались, они все равно вас на чем-нибудь да проведут, надо только, чтоб это было не самое главное, чтоб они вам черное в белое не превратили... (Ю. Домбровский). Помнишь, как Федор Иоаныч говорит: я не умен и не силен, меня обмануть не трудно, но белое от черного я отличить могу! (А. Солженицын) [5,с.24].

В семантическом пространстве аксиологической оппозиции можно выделить как минимум два уровня: эмпирический, отражающий первый этап столкновения человека с явлениями, лежащими в основе оппозиции, 
и символический, показывающий, какие признаки диады важны для языкового сообщества при интерпретации окружающей действительности. Так, в семантике бинарной оппозиции отражаются естественные этапы процесса познания явлений действительности: анализ - мысленное расчленение объектов на составные части с целью выявления составляющих его элементов и отделения существенного от несущественного - и синтез, являющийся «вершиной чувственного познания, той его стадией, когда оценочные компоненты носят не инстинктивно-стихийный характер, а обусловливаются наглядно-познавательной деятельностью индивидуума» $[2$, с. 12].

В зависимости от внешних особенностей оппозиции, ее значимости для человека на первом уровне ее многослойного содержательного пространства выделяются первостепенные, доминантные признаки (у компонента белый - это признаки «чистый», «выделенный», «светлый», «открытый»; у компонента черный - «грязный», «темный», «спрятанный», «интенсивный»), которые, переходя на другой уровень содержания, рождают новые, символические смыслы.

В результате человек выбирает существенно важные для него оппозиции и оперирует ими при оценке разных сфер своей жизнедеятельности. Опираясь на данные Национального корпуса русского языка, можно констатировать, что диада «белый-черный» лежит в основе интерпретации следующих условно выделенных сфер: эмоциональной, этической, социально-правовой, гносеологической.

В эмоциональной сфере белый цвет символизирует радость, добро, чистоту, невинность; черный - пессимизм, невезение, несчастие, безнадежность: И такой это был чистый белый мир на черной еще земле, такое свечение!.. (В. Шукшин) [3,с.89].

В этической сфере белый цвет - символ доброты, нравственности; черный цвет - символ подлости, безнравственности: Бело твое платье, а душа еще белей! (И. Тургенев); Свет бел, да люди черны (пословица). Черное лицо и белое лицо - вот какая разница! Черное лицо и белая душа. Белое лицо и черная душа (С. Довлатов) $[4, c .112]$.

В социально-правовой сфере белый цвет - символ законного, юридически правильного; черный цвет - символ незаконного, требующего юридических последствий: Если нам предложат отличную станцию, но только чтобы ее купить, нужно заплатить 1 руб. со счета, а еще десять в мешке принести, да еще половина бухгалтерии «белая», половина - «черная», тогда нет. Это было связано с тем, что «белый» лизинг с последующим переходом права собственности гораздо выгоднее «черной» аренды [2,с.15].
Говоря об аксиологической метафоре, важно отличать языковую символику от символики культурной. Первая реализуется в языке, создавая многослойную семантику лексических единиц путем перехода от конкретного к абстрактному: белая душа, черная зависть, белый каталог, черный пиар. Вторая привязана к предмету, несущему определенный культурно закрепленный смысл, и только обозначается языковыми средствами.

Таким образом, аксиологическая бинарная оппозиция «белый/черный» пронизывает современный русский язык, создавая условия для реализации ее метафорического потенциала и в определенной степени влияя на сознание носителя языка. Изучение особенностей и закономерностей работы подобных диад позволит понять механизм постижения действительности и ее оценивания.

Выделенные аспекты весьма абстрактно представляют шаги последовательного освоения человеком (через свои переживания, через интуицию) бинарной оппозиции: от освоения значимости ее физических свойств для практической деятельности человека к освоению значимости ее физических свойств для оценочной и классифицирующей деятельности и, в конечном счете, для языкового моделирования мира, осознания его сложности и многоаспектности.

В адыгской лингвокультуре слово фыжъы/хужъ «белый» этимологически связано с нэф/нэху «свет», мафэ/ махуэ «день», что отражается в значении белого, выступающего с благоприятным знаком.

Слово ш1уыц1э/ф1ыцэ «черный» объединяется общностью компонента ш1уы-/-ф1 с ш1уынк1/к1ыф 1 «темнота, мрак, черное» и, противопоставляясь белому, приобретает отрицательный символический смысл.

В цветовой метафоре обнаруживается много общего в русской и кабардинской культурных традициях, что связано с универсалиями в ритуальной символике.

В русской лингвокультуре: «чёрный» - чёрного цвета, масти, самый тёмный, цвета сажи. Чёрен арапчонок, черным - чернёхонек, чернее сажи чёрной.

Белый цвет символизирует благо, чёрный - зло. Ср. каб. 1ашэмэз, жа1э, йыбжъамийр Тхъэгъэлэдж бжъамийт, ялейт: бжъамийм йык1апит1ым языр кйэхут, абы къыпэшъытыр еынду ф1ыц!эт. Бжъамийм йыкктэхуым уепшъэмэ абы ййымакъым дуней ибылъэр фйыгъуэу хуигъэбэтырт. Ауэ адрей к1апэ ф1ыц1эмуепшъэмэ, абы къик1 макъым ш1ым ф1ыгъуэу телъыр тыригъэбзэхык1ырт [3,с.45].

«Свирель у Ашамеза, говорят, была Тхагаледжева сви- 
рель, удивительная: один конец свирели белый, другой чёрный, как ворон. Подуешь из белого конца - звук наполняет землю богатством и добром. Но если подуешь из чёрного конца - земля лишается всего богатства и добра» $[10, c .169]$.

В адыгской мифологии белый цвет используется также для характеристики главной героини нартского эпоса - Сатаней. Слово фыжьы/хуыжъ «белый» входит в состав характеризующих её средств, в том числе эпитетов: бгышъхъэ уэс нэхуынэ - «белый снег вершины», «жъэгъуыху» «с белой шеей»,» бгъэху» «с белой грудью».

В русской лингвокультурной традиции концепт «белый»-о цвете, масти, краске: бесцветный, противный чёрному. В сравнительном смысле светлый, бледный: белый хлеб, белое вино, белое лицо. Чистый, не- запятнанный. Белый платок, белая рубаха, белый пол. Рубаха черна, да совесть бела. Говорит бело, да делает черно. Свет бел, да руки черны.

В отличие от белого, чёрный цвет символизирует грозу, опасность, недоброе.

Итак, поскольку национальная культура - это память народа, его сознание репрезентируется в составляющих менталитета нации, таких как национальное мышление, национальная картина мира, когнитивное пространство, концептосфера и пр. Также в этих оппозициях важное место занимает символическая часть, благодаря ей данная оппозиция превращается в аксиологическую метафору, которой человек оперирует при постижении и описании явлений окружающего мира.

ЛИТЕРАТУРА

1. Абазова К.В. Языковая репрезентация цвета: лингвокультурологический аспект : на материале кабардино-черкесского, английского и русского языков : автореферат дис. ... кандидата филологических наук: Нальчик, 2009. - 21 с.

2. Арутюнова Н.Д. Язык и мир человека. - М.: Языки русской культуры, 1999. - 896 с.

3. Глазунова 0.И. Логика метафорических преобразований. - СПб.: Филологический факультет СПбГУ, 2000. - 190 с.

4. Гутов А. Адыгские сказания о нартах// Народные песни и инструментальные наигрыши адыговю-М.,1981

5. Дорожкина Т.Н. Члены языковой оппозиции «черный-белый»: лексическая и прагматическая семантика // Исследования по семантике. - Уфа, 1999. - С. 6-17.

6. Колесов В.В. Русская историческая лексикология и лексикография. Вып. 3. - Л.: ЛГУ, 1983. - С. 8-16.

7. К Кузнецов С.А. Большой толковый словарь русского языка. - СПб.: Норинт, 1998. - 1536 с.

8. Ожегов С.И., Шведова Н.Ю. Толковый словарь русского языка. - М.: Азъ, 1992. - 955 с.

9. Фасмер М. Этимологический словарь русского языка: в 4 т. - М.: Прогресс. Т. 1 - 1986. - 576 с.; Т. 4. - 1987. - 864 с.

10. Цивьян Т.В. Модель мира и ее лингвистические основы. - М.: ДомКнига, 2005. - 280 с.

11. Шагиров А.К. Этимиологический словарь адыгских (черкесских) языков. Ч.1А. -М.1977 